\title{
Analysis on the Modular Teaching of International Marketing Course Based on Development of China's Higher Education Service Trade
}

\author{
Yao $\mathrm{Li}^{1 *}$ \\ ${ }^{1}$ College of Business Administration, Haikou University of Economics, Haikou, Hainan, 571127, China \\ *Corresponding author.Email: liyao1005@163.com
}

\begin{abstract} that meet the actual needs of the society. Higher Education Service Trade

\section{DEVELOPMENT STATUS OF CHINA'S HIGHER EDUCATION SERVICE TRADE}

China's higher education service trade has developed rapidly in recent years. On the whole, it generates low revenues despite of its large scale when compared with developed countries[1]. In the era of Hainan's deepening of its all-round reform and opening-up, the superiority of modular teaching methodology has become increasingly prominent in response to the curriculum construction of applied undergraduate colleges and universities. Based on the actual situation in Hainan and the Modules of Employable Skills(MES) teaching concept, this article designs the modular construction of the International Marketing course in detail with a view to cultivating application-oriented marketing talents with comprehensive qualities and capabilities

Keywords: International Marketing Course, Modularized Teaching, Modules of Employable Skills(MES),

\subsection{The market of higher education service trade concentrating on developed countries}

In the 30 years from the early years of the founding of the People's Republic of China to the start of the reform and opening up, China's foreign cultural exchanges and cooperation were mainly carried out within the socialist countries[2]. The recruitment of foreign students was aimed at helping developing countries to cultivate scientific and technological talents instead of aiming for profit. China's trade in higher education services in its true sense began in the late period of reform and opening up. Since the 1980s, the scale of China's higher education service trade has gradually expanded. However, due to the late entry into the WTO, the export of education service trade has not yet formed a sound market operation mechanism and corresponding supporting laws and regulations, there is a vast gap when it is compared with the major exporting countries of higher education services, such as European and American countries, Australia, New Zealand, Japan[3].

According to China's commitment to the signed Schedule of Concessions on Trade in Education Services, China's education service trade market will be liberalized step by step[4].

At present, the export share of China's higher education in education service trade is at a distinct disadvantage, which is far less than the economic benefits obtained by developed countries. According to the trade commitment of China's higher education to the Education Services (ES) in the General Agreement on Trade and Service (GATS), the number of foreign students receiving formal academic education and non-formal qualifications in China has increased year by year, however, despite its wide coverage, it still cannot get rid of a few shortcomings.

\subsection{The rapid development in China's higher education service trade}

Thanks to the following four factors, China's higher education service trade is developing rapidly, though there is still a large gap with developed countries[5].

First of all, China's higher education reform and opening up policy provides a legal basis for education service trade. In May 1985, the central government promulgated the Decisions on the Reform of the Education System. Universities across the country experienced a rapid development stage of merger and expansion of enrollment, forming a new pattern of China's higher education development. In July 1994, the State Council issued the Opinions on the Implementation of the Outline of China's Educational Reform and Development and implemented the '211'project. In August 1998, the National People's Congress formulated and issued the Higher Education Law of the People's Republic of China, once again highlighting the cultivation of senior professionals and autonomy in running schools. Under the guidance of China's higher education policy, colleges and universities gradually improve their own development and further open up to the 
outside, which contribute to China's higher education service trade forming a rapid development trend.

Secondly, the improvement of China's comprehensive national strength has promoted the development of higher education service trade[6]. The development of trade in higher education services is an important indicator of the development level of a country's comprehensive national strength. In 1978, China received only 1,236 foreign students. In 2008, it reached 223,500. In 2016, it reached nearly 442,800, 358 times more than 30 years ago. According to the statistics of the Ministry of Education of China, by the end of 2017, a total of 489,200 foreign students from 204 countries and regions have studied in 935 institutions of higher learning in 31 provinces, autonomous regions and municipalities across the country. The growth rate has remained at $10 \%$ for two consecutive years; among them there are about 241,500 academic students, accounting for $49.38 \%$ of the total, which shows an increase of $15.04 \%$; the total number of master's and doctoral students is about 75,800, an increase of $18.62 \%$ over the figures in 2016.

Thirdly, the connotation construction of China's higher education is the basis for the rapid development of higher education service trade. Since the beginning of the 21st century, China's higher education has entered the stage of connotation construction after experiencing the stage of scale development. Universities in various regions have continuously optimized the structure and the features of running schools in the reform, meanwhile, universities have gradually improved the construction of disciplines and the quality of teaching. The high-tech subjects and special subjects is gradually showing their advantages in educational service trade.

Fourthly, the 'Belt and Road Initiative' promotes the development of China's higher education service trade. With the promotion of the 'Belt and Road Initiative' and China's preferential support for foreign students in the countries along the line, such as the enrollment, employment and other policies, the trade in higher education services has developed rapidly. According to the statistics of the Ministry of Education in 2016, the average increase in the number of students studying in China along the 'Belt and Road' countries such as Thailand, India and Pakistan has exceeded $20 \%$, which not only greatly eased the deficit in studying abroad, but also accumulate talents so as to deepen China's participation in globalization and global governance.

\section{AN OVERVIEW OF MODULAR TEACHING}

Modularized teaching mode and modular operations in industrial production share much common ground. It decomposes subject knowledge into many knowledge points, and then combines related knowledge points into relatively independent units on the basis of certain logical relations[7]. In the course of teaching practice, the specific module combination depends on the needs of the professional technical fields and the occupational post groups[8]. This teaching method is different from the traditional approach in the past. The traditional teaching process focuses more on the integrity and systematicness of the teaching content, while the modular teaching emphasizes the practical application of the theory. The modular teaching objectives are more explicit and targeted, which lay emphasis on the improvement of students' comprehensive ability. One module corresponds to one teaching unit. Through various teaching methods, it strives to cultivate application-oriented marketing talents with comprehensive qualities and capabilities that meet the actual needs of the society.

At present, the studies on modular teaching aboard are mainly divided into two schools, MES (Modules of Employable Skills) and CBE (Competency Based Education). The former refers to modular skill training, which was researched and developed by the International Labour Organization in the early 1970s. This education model considers skill training as the core and focuses on on-site teaching[9]. It is also called Tasks Module, as it always focuses on how to complete the actual job tasks. CBE refers to competency-based education[10]. This teaching model gains popularity in the United States and Canada. It is based on the ability needed to develop a certain business.

In other words, the designing of the study modules is based upon the ability to execute. Revolving around the cognitive and activity abilities required for a certain profession, it is also called the ability module.

\section{THE PURPOSE AND SIGNIFICANCE OF MODULAR CONSTRUCTION OF INTERNATIONAL MARKETING COURSE}

After the Central Committee of the Communist Party of China issued the Guiding Opinions on Supporting Hainan's Comprehensive Deepening of Reform and Opening-Up, Hainan actively launched the construction of free trade zones (ports) and international tourism consumption centers. In the foreseeable future, the trade and investment activities of other countries in Hainan will surge rapidly, the scale and scope of the international operations of multinational companies will be increasingly expanding, and the international management of enterprises will become a trend. Driven by the trend of internationalization, the domestic industries hope to enter the international market in order to grab more growth opportunities. Under the condition that domestic market and international market become more and more closely related[11], the pressure from foreign market competition also requires enterprises to take the influence of international market into account even if they are operating in domestic market. Under such background, it is increasingly crucial for marketing major students to master a whole set of international marketing theories and methods[12]. 
Based on the field research on the needs of enterprise post groups, the modular construction of the International Marketing course determines the competence groups that marketing students should possess, 'eliminates, integrates, and adds' the original course content through combining theory with practice, summarizes the essence of marketing experience at home and abroad, absorbs cutting-edge research achievements in marketing management, combines the practice of China's opening-up to the outside world and the actual situation of domestic and foreign enterprises engaged in international marketing activities in an effort to cultivate application-oriented talents of highquality and strong capabilities for the construction of Hainan Free Trade Zone and to output inter-disciplinary talents who understand both planning and sales[13]. This creative research and teaching attempt on the course holds high theoretical value and significant application value, and has important practical significance for innovative modular teaching thinking as well[14].

\section{THE CONCRETE IDEAS ON THE MODULAR CONSTRUCTION OF THE INTERNATIONAL MARKETING COURSE}

The International Marketing course of the Bachelor of Marketing major at the Haikou School of Economics focuses on MES teaching. There is not much research on the modular teaching of this course in domestic marketing majors, and it is mainly concentrated on marketing courses in vocational colleges.

Through the elimination, integration and addition of existing course content, Modular construction of International Marketing course attempts to integrate the original 12 chapters of the course finally into four major curriculum groups that meet the needs of enterprise post groups: Cross-cultural Communication and Management Module, Green Marketing module, International Brand Management Module, Cross-border E-commerce Module. The original course include the follow chapters: Introduction to International Marketing; International Cultural, Economic, Political and Legal Environment; International Consumption Behavior analysis; International Market Segmentation and Target Market Selection; International Market Entry and Competition Strategies; International Market Products, Prices, Channels, Promotion Strategies.

The specific content is shown in Figures 1 and 2.

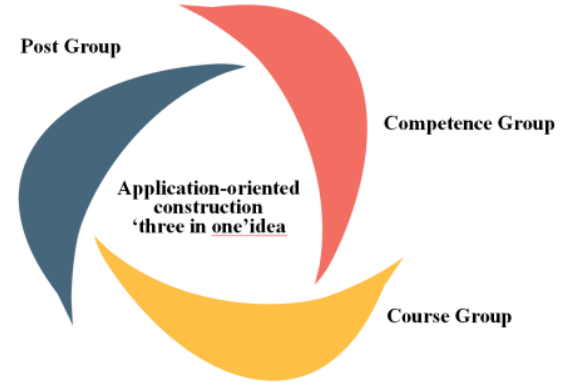

Figure 1 Application-oriented construction 'three in one' idea

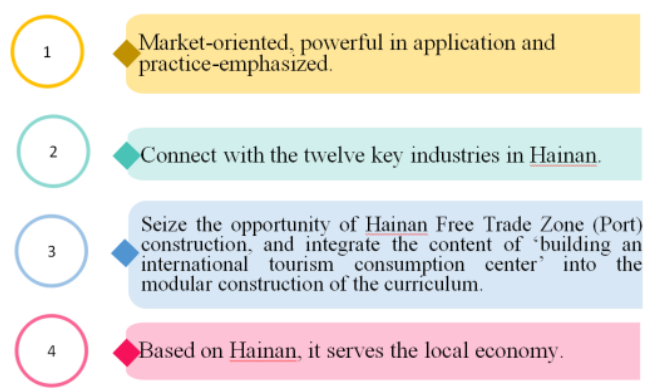

Figure 2 General Idea on Modular Teaching of International Marketing Co

The content of this course design covers the overall idea of modular construction of the course, the 'three in one' idea of application-oriented construction, the specific content of the modular reform of the course, the path of the 'trinity' construction of the modular course, the construction of the curriculum connotation and the future development plan of the modular construction[15]. It aims to solve problems such as the lack of emphasis in the previous courses, repeated teaching of relevant theoretical content, and insufficient practical teaching.

Through the construction of modular courses, the repeated content is eliminated, the related content is integrated, and new content is added to make the course more targeted and practical. It strives to make the International Marketing course more in line with the application-oriented undergraduate training objectives in an efforts to effectively meet the post and capacity needs of Hainan to build a free trade zone(port) and international tourism consumption center.

The specific content is shown in Figures 3.

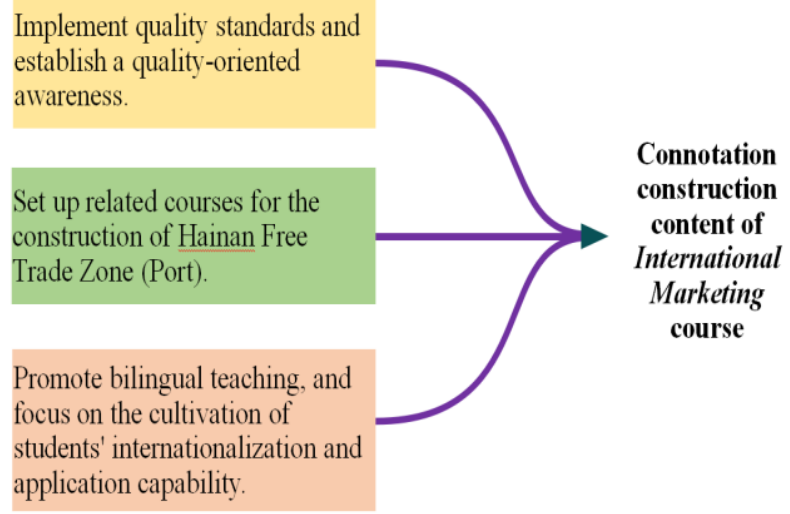

Figure 3 Connotation construction content of International Marketing course

\section{CONCLUSION}

With a broad knowledge coverage and targeted methods, modular teaching methodology can basically reflect the actual acquisition of the student's knowledge and in the 
meantime improve students' application ability to apply theory to practice by means of teaching. In addition, it is necessary to adjust and improve the weight of grading of students' usual performance in the evaluation of student's academic achievement of the modular course of International Marketing. Special attention should be given to guide students to understand, analyze and apply international marketing ideas and strategies, which are conducive to better internationalization of the course and to actively participate in the education service trade.

\section{ACKNOWLEDGMENT}

This work was supported by:

1. Haikou University of Economics teaching, research and teaching reform; project name: International Marketing course modular construction research; project number: hjyj2018011.

2. Haikou University of Economics Project; Project Name: Hainan \& Taiwan Education Industry Cooperation Development Research; Project Number: HJKY(YB)19-11.

3. Haikou City Philosophy and Social Science Planning Project; Project Name: Research on the Cross-border Integration and Innovation Development of Culture, Tourism and Education Industry in Haikou Based on the Triple Helix Theory; Project Number: 2020ZZKT-11.

\section{REFERENCES}

[1] Liu Fengxiang, New Trends and Inspirations of Foreign Direct Investment in 2012 [J], International Economic Cooperation, 2013 (No. 327), pp. 27-28.

[2] Liu Fengxiang, An Analysis of Diversification of International Cooperation [J], Frontier, 2011 (12), pp. 3539.

[3] Wei Hao \& Ji Ying, The status quo and international competitiveness of China's education service trade abroad [J], International Economic Cooperation, 2010 (01), pp. 57-58.

[4] Deng Guoqing, China's international education service trade development status and countermeasures [J], Chinese and foreign education research, 2008 (11), pp. 106-109.

[5] Xiao Hai \& Liu Fang, Status and advantages of higher education service trade in developed countries and China's countermeasures $[\mathrm{J}]$, Jiangxi Education Research, 2007 (06), p 29.

[6] Jin Xibin, International Education Service Trade Research [J], Journal of Beijing Normal University (Social Science Edition), 2004, Issue 1 (Issue 181), pp.46-49.

[7] Chen Qiang \& Pan Huibin, On the Education Development of International Students in China [J], China Higher Education Research, 2006 (08), pp. 112-117.

[8] Xiao Zhuoyang, Research on the Modular Teaching and Cultivation Mode of Higher Vocational Specialty Based on PDCA Cycle_- Taking Marketing Major as an Example, China Vocational and Technical Education, 2017 (11), pp. 39-43.

[9] Dai Xinzhe, A Probe into the Design of Modular Teaching Curriculum for Marketing Planning, Liaoning Vocational College Journal, 2017 (02), p 55.

[10] Bai Lin, Research on modular teaching of luxury jewelry exhibition marketing, Shanxi Education (Higher Education), 2016 (03), p 67.

[11] Zhong Jingling, Modular teaching reform of marketing major in newly-built undergraduate colleges, Journal of Guangdong Jiaotong University, 2015, pp.63-67.

[12] Zhang Dong \& Xiao Zhixiong, Discussion on the theory of modular teaching model of marketing courses in colleges and universities, 2015 (06), p 36.

[13] Wang Wen, Discussion on the module teaching mode of marketing and planning major in vocational colleges, Vocational education, 2012 (10), pp. 111-114.

[14] Zhu Weilian, Ministry of Yan'an. Analysis of the path of practice teaching docking inside and outside vocational colleges, Vocational and Technical Education, 2011(05), p 37.

[15] Pan Chunyan, Thinking on the Construction of Compound Talents and Their Cultivation Model, Theory of Learning, 2010 (07), pp 12-16. 